\title{
Selected Varieties of Dioscorea alata L., the Asian Greater Yam ${ }^{1}$
}

\author{
Franklin W. Martin, Eugenio Cabanillas and Rubén Guadalupe ${ }^{2}$
}

\section{ABSTRACT}

Each of more than 300 varieties of $D$. alata collected throughout the tropics have been evaluated for 100 observable characteristics in the field, at harvest, and in the laboratory and kitchen. Concepts of quality were developed from these observations and these have been used to select better varieties. Six excellent commercial-type varieties (Florido, Smooth Statia, Forastero, Veeven, Gemelos and Leone Globe) are the results of these selections which now are available for distribution throughout the tropics.

\section{INTRODUCTION}

Improved varieties of Dioscorea alata L. (also known commonly as the Asian greater yam, the 10-months yam, or the water yam) apparently cannot be produced by typical plant-breeding techniques. No systematic breeding has been reported. Seedlings have not been described. Existing varieties seldom flower. When they do, the flowers usually are sterile, perhaps partly because of their polyploid status. The sources of current varieties are unknown, but presumably they are very old; perhaps ancient. The traditional method of planting from tuber pieces or from small tubers continues to be the principal mode of propagation. Because several related varieties are often grown in a given geographical area, it appears that some variation has occurred through mutation.

Because of the limitations to conventional breeding, better varieties can be obtained only through selection. Because $D$. alata came into cultivation first, possibly in Burma or New Guinea, its varieties have been widely distributed by man, so that given areas are often characterized by a few well-known varieties that often have no particular advantage over others available in nearby regions. To obtain good adapted varieties, yams must be collected from many regions, and then compared and selected where their use is intended.

A collection of more than 300 varieties of $D$. alata has been assembled, grown, and evaluated at the Mayagüez Institute of Tropical Agriculture,

1 Manuscript submitted to Editorial Board October 11, 1974.

2 Plant Geneticist and Research Technician, Mayagüez Institute of Tropical Agriculture, Agricultural Research Service, U.S. Department of Agriculture, Mayagüez, Puerto Rico; Assistant Horticulturist, Food Technology Laboratory, Agricultural Experiment Station, Río Piedras, Puerto Rico. 
Puerto Rico. A duplicate collection was also maintained at Isabela, Puerto Rico, under conditions of contrasting climate and soils. From studies of these collections, very definite ideas have been obtained as to what constitutes a good variety of this species of yam, and exceptional selections are now available.

A good variety of $D$. alata is resistant to leaf spot diseases and viruses, and is not affected adversely by excessive moisture. The tubers are borne in pairs or in threes, are spherical or cylindrical in shape, are not often branched, and have smooth but thickened skin that resists abrasion. Their surface may have some fine roots, but the principal roots should be concentrated in the fibrous upper extreme of the tuber. Resistance to insects, diseases and nematodes is desirable. Yields must be high and dependable, even when the crop is produced without support for the climbing vines.

Some special characteristics related to cooking are desirable in addition to these varietal characteristics. The parenchyma storage flesh should be white or cream colored, and free of anthocyanin pigments. The "grain" of the tuber caused by starch accumulation around the vascular bundles should be fine, giving a compact and uniform appearance. After being cut, the flesh should not discolor readily by oxidation, and preferably the tuber should be somewhat resistant to oxidation and discoloration associated with injury and storage. The boiling time necessary to reach an acceptable softness may vary, but the better varieties generally reach this stage rapidly. The cooking water should remain free of grey or pink pigments. The flesh of the boiled tuber may be white, cream, or light yellow, appetizing in appearance, and free from grey color. It should appear to be smooth and that appearance verified when tasted. The cooked tuber should be moist in the mouth; not dry and difficult to swallow. The taste should be rich and distinctive, neither too bitter nor too sweet.

In addition, the variety should produce good yields (20 tons/hectare or more), the tubers should store well and resist fungi, and the seed pieces should germinate readily when planted.

No variety the authors have seen combines all desirable characteristics. Selection of new varieties thus becomes a matter of compromise.

\section{METHODS AND MATERIALS}

Cultivars of yams were obtained by purchase or exploration in the Caribbean, West Africa, and by exchange and correspondence with persons throughout the tropics. A large collection of these cultivars from Southeast Asia will require evaluation over several years. Some duplications have been found among the accessions and other duplications may exist. An exact accounting thus is not possible, but about 300 varieties were involved in these studies. 
Each accession in the collection was evaluated for 100 characteristics observed in the field, at harvest, or in the laboratory both before and after cooking. These characteristics were studied by correlation techniques ${ }^{3}$ which made possible the prediction of cooking quality through observation of foliar and tuber characteristics. From the cvaluation process, clear concepts of quality of cultivars were established.

Using concepts of quality, inferior cultivars were eliminated until only 19 remained. These remaining cultivars were subjected to close examination during one to three additional seasons, in at least two contrasting soil types (heavy clay, light loam). Most of the cultivars were included in replicated yield trials.

From the more detailed observations, six varieties were selected as superior for commercial-type purposes. Seven varieties were selected as suitable for home production. Three varieties were selected for possible use as animal feeds. Three varieties were discarded.

\section{RESULTS}

Inspection of many cultivars showed that the species $D$. alata covers a vast range of local types, many of which are completely unsuitable for home or commercial use when better varieties are available. All varieties tested, however, were judged edible, even if not appetizing or agronomically suitable.

The following defects were encountered in many varieties: tubers too long or irregular in shape to permit easy harvest or preparation in the kitchen, flesh inferior before or after cooking because of polyphenolic oxidation, presence of pigments, off-flavors, or other similar disagreeable features, or inadequate yields. Nineteen varieties were selected that showed outstandingly desirable features. These selections then were further tested more systematically taking the noted defects into consideration when making the final selection.

The 19 varieties finally selected are given in table 1 , together with information concerning their recent geographical origins, a few of their strengths or weaknesses, and a judgment of appropriate use of each.

A few of the many characteristics rated in the field or at harvest are given in table 2. Anthocyanin content is negatively correlated with tuber quality. Amost all of the selections had very little anthocyanin in the foliage. The selections varied in susceptibility to leaf-spot disease, the most troublesome condition limiting yam production. Complete resistance was not seen in any variety. In addition, differences were seen in expression of virus symptoms. The virus diseases of yams are not understood well

- Martin, F. W. and Rhodes, A. M., Correlations among greater yam (Dioscorea alala L.) cultivars, Trop. Agric. (Trinidad) 50: 183-192, 1973. 
enough for evaluation of these differences. Slight differences were seen in time of maturity. The earliest varieties mature no more than a month before the latest. Varieties differed in yields, and these differences were consistent over the observation period.

After harvest, the characteristics of individual tubers were tabulated (table 3). Within any variety, considerable variation was caused by mal-

TABLE 1.-Information on outstanding characteristics, principal defects, and recommendations for use of Dioscorea alata selections

\begin{tabular}{|c|c|c|c|c|}
\hline Common name & Recent source & Outstanding characteristic & Principal defect & $\begin{array}{l}\text { Recommendation } \\
\text { for use }\end{array}$ \\
\hline Florido & Puerto Rico & Quality & $\begin{array}{l}\text { Leaf spot sus- } \\
\text { ceptibility }\end{array}$ & Commerce \\
\hline Smooth Statia & Puerto Rico & Shape, flavor & $\begin{array}{l}\text { Virus suscepti- } \\
\text { bility }\end{array}$ & Commerce \\
\hline White Lisbon & Trinidad & Quality & Shape & Home \\
\hline Prolific & India & Yield & Quality, shape & Feed \\
\hline Forastero & Puerto Rico & Yield, quality & Shape & Commerce \\
\hline Belep & New Caledonia & Yield & Shape & Feed \\
\hline Pacala & West Africa & Quality & $\begin{array}{l}\text { Leaf spot sus- } \\
\text { ceptibility }\end{array}$ & Home \\
\hline Veeven & Nigeria & $\begin{array}{l}\text { Yield, disease-tol- } \\
\text { erance }\end{array}$ & Flesh oxidation & Commerce \\
\hline Beka & Fiji & Disease-tolerance & Quality & $\begin{array}{l}\text { Not recom- } \\
\text { mended }\end{array}$ \\
\hline Murapoi & Fiji & Shape & Quality & Home \\
\hline Gemelos & Puerto Rico & Yield, quality & Branching & Commerce \\
\hline Suidie & Ivory Coast & Quality & Yield & Home \\
\hline Puka & Ghana & Quality & $\begin{array}{l}\text { Leaf spot sus- } \\
\text { ceptibility }\end{array}$ & $\begin{array}{l}\text { Not recom- } \\
\text { mended }\end{array}$ \\
\hline Alowinrin & Nigeria & Disease-tolerance & Fair yield & Home \\
\hline Onwala & Nigeria & Shape & Vigor, yield & Home \\
\hline Nsukka & Nigeria & Disease-resistance & Yield & Home \\
\hline Grandote & Nigeria & Yield & Quality & Feed \\
\hline Ewura Oya & Nigeria & Disease-tolerance & Yield, quality & $\begin{array}{l}\text { Not recom- } \\
\text { mended }\end{array}$ \\
\hline Leone Globe & Sierra Leone & Yield, quality & Irregular shape & Commerce \\
\hline
\end{tabular}

formation of tubers by soil conditions, but a typical shape was discernible. Shape depends on many intrinsic factors; including tendency to grow in length instead of in width, and the degree of branching and the site thereof. These characteristics, as well as smoothness of surface and quantity of roots, influence the ease of harvest by either hand or mechanical techniques, and the ease of processing the tuber in the kitchen or factory.

Finally, important characteristics contributing to quality, observed or measured in the laboratory, are given in table 4 . The characteristics ob- 
TAвL: 2.-Field and foliage characterislics, and yielding tendency

\begin{tabular}{|c|c|c|c|c|c|c|}
\hline Common name & Sprouting & $\begin{array}{l}\text { Anthocyanin } \\
\text { content }\end{array}$ & Virus & $\begin{array}{l}\text { Susceptibility } \\
\text { to leaf-spot } \\
\text { (Candelilla) }\end{array}$ & $\begin{array}{l}\text { Time of } \\
\text { maturity }\end{array}$ & $\begin{array}{c}\text { Yield } \\
\text { tendency }\end{array}$ \\
\hline Florido & IXxcellent & None & Susceptible & $\begin{array}{l}\text { Very suscepti- } \\
\text { ble }\end{array}$ & Early & Average \\
\hline Smooth Statia & Good & Almost none & Average & Average & Average & Average \\
\hline Farm Lisbon & lixcellent & Almost none & Average & Average & Average & Good \\
\hline Prolific & Good & Almost none & Resistant & Resistant & Mid-senson & Excellent \\
\hline Forastero & Late & None & Resistant & $\begin{array}{l}\text { Sometimes sus- } \\
\text { ceptible }\end{array}$ & Late & Excellent \\
\hline Belep & Fair & Almost none & Unknown & Tolernnt & Average & Fxcellent \\
\hline Pacala & Good & None & Unknown & Average & Average & Average \\
\hline Veeven & Poor & Almost none & Unknown & Average & Average & Good \\
\hline Beka & Average & Considerable & Unknown & Average & Average & Avernge \\
\hline Murapoi & Fair & Very little & Unknown & Resistant & Average & Good \\
\hline Gemelos & Excellent & Considerable & Unknown & Tolerant & Late & Excellent \\
\hline Puka & Poor & Considerable & Unknown & Susceptible & Early & Poor \\
\hline Alowinrin & Excellent & Almost none & Unknown & Average & Early & Fair \\
\hline Onwala & Good & Almost none & Unknown & Average & Average & Fair \\
\hline Nsukka & Giood & Almost none & Unknown & Average & Late & Fair \\
\hline Girandote & Fair & Considerable & Unknown & Resistant & Late & Excellent \\
\hline Ewura Oya & Fair & Almost none & Unknown & Average & Average & Fair \\
\hline Leone Globe & Poor & None & Unknown & Resistant & Late & Excellent \\
\hline
\end{tabular}


TABLE: 3.-Tuber characteristics

\begin{tabular}{|c|c|c|c|c|c|c|c|}
\hline Common name & $\begin{array}{c}\text { Tubers } \\
\text { per plant }\end{array}$ & Tuber shape & $\begin{array}{l}\text { Tendency } \\
\text { to branch }\end{array}$ & Place of branching & Smoothness of bark & $\begin{array}{l}\text { Surface } \\
\text { roots }\end{array}$ & $\begin{array}{l}\text { Sum- } \\
\text { mary } \\
\text { rating }\end{array}$ \\
\hline Florido & $1-2$ & Jillipsoidal & Low & - & Very smooth & Few & 5 \\
\hline Smooth Statia & 1 & Spindle & Very low & - & Very smooth & Few & 1 \\
\hline Farm Lisbon & $1-2$ & Deltoid & High & Low & Rough & Some & 3 \\
\hline Prolific & 1 & Deltoid & High & Irregular & Smooth & Few & 3 \\
\hline Forastero & $1-2$ & Clavate & Low & - & Smooth & Few & 4 \\
\hline Belep & 1 & Deltoid & Low & - & Slightly rough & Few & 3 \\
\hline Pacala & 1 & Cylindrical & Low & - & Smooth & Some & 3 \\
\hline Veeven & $1-2$ & Short cylindrical & Jow & - & Smooth & Some & 3 \\
\hline Beka & $1-2$ & Like hands & High & Middle to low & Smooth & Some & 3 \\
\hline Murapoi & $1-3$ & Globular & Low & - & lough & Few & 3 \\
\hline Gemelos & $2-4$ & $\begin{array}{l}\text { Short cylin- } \\
\text { drical }\end{array}$ & Low & Irregular & Smooth & Few & 5 \\
\hline Suidie & 1 & Long spindle & Very low & - & Very smooth & Few & 3 \\
\hline Pukil & 1 & $\begin{array}{l}\text { Rough globu- } \\
\text { lar }\end{array}$ & High & All over & Very rough & Some & 2 \\
\hline Alowinrin & $1-2$ & Spindle & Very low & - & Slightly rough & Some & 2 \\
\hline Onwala & 1 & $\begin{array}{l}\text { Stout eylin- } \\
\text { drical }\end{array}$ & Low & - & Slightly rough & Some & 1 \\
\hline Nsukka & $1-2$ & Gilobular & High & Mid to top & llough & Few & 1 \\
\hline Cirandote & 1 & $\begin{array}{l}\text { Flattened cylin- } \\
\text { drical }\end{array}$ & low & - & Smooth & Few & 2 \\
\hline Ewura (Oya & $1-2$ & $\begin{array}{l}\text { Compact cylin- } \\
\text { drical }\end{array}$ & Medium & High & Rough & Few & 1 \\
\hline Leone Globe & $1-6$ & $\begin{array}{l}\text { Irregular } \\
\text { globular }\end{array}$ & High & Many sites & Rough & Few & 3 \\
\hline
\end{tabular}

1 Rated from 1 (poor) to 5 (excellent). 
TABL: 4.-Kitchen and culinary characteristics

\begin{tabular}{|c|c|c|c|c|c|c|c|c|}
\hline Common name & $\begin{array}{l}\text { Ease of } \\
\text { peeling }\end{array}$ & Color of flesh & Oxidation & Texture & Appearance & Moisture & Flavor & $\begin{array}{l}\text { Summary } \\
\text { rating }\end{array}$ \\
\hline Florido & Easy & Light cream & Low & Regular & Good & Average & Excellent & Good \\
\hline Smooth Statia & Easy & Cream & Average & Coarse & Excellent & Average & Good & Good \\
\hline White Isisbon & Difficult & Light cream & Low & Smooth & Very good & Average & Excellent & Good \\
\hline Prolific & Difficult & Cream & Average & Coarse & Fair & Regular & Fair & Fair \\
\hline Forastero & Average & Light cream & Low & Smooth & Excellent & $\begin{array}{l}\text { Above } \\
\text { average }\end{array}$ & Fxcellent & Excellent \\
\hline Belep & Difficult & Light cream & Low & Smooth & Average & Regular & Regular & Average \\
\hline Pacala & Regular & Light cream & Low & Smooth & Good & High & Excellent & Giond \\
\hline Veeven & Easy & Cream & Regular & Regular & Average & Regular & Fair & Good \\
\hline Beka & $\begin{array}{l}\text { Very } \\
\text { difficult }\end{array}$ & Cream & High & Coarse & Poor & Regular & Regular & Fair \\
\hline Murapoi & Average & Dark cream & High & Coarse & Poor & Average & Poor & Poor \\
\hline Gemelos & Fasy & Light cream & Regular & Regular & Excellent & Regular & Good & Good \\
\hline Suidie & Easy & Light yellow & Low & Smooth & Excellent & High & Excellent & Excellent \\
\hline Alowinrin & Easy & Cream & Regular & Coarse & Fair & High & Good & Fair \\
\hline Onwala & Easy & Light cream & Low & Smooth & Good & Regular & Good & Good \\
\hline Nsukka & Easy & Light cream & Regular & Regular & Good & High & Good & Good \\
\hline Grandote & Average & Cream & Average & Coarse & Average & High & Average & Good \\
\hline Ewura Oya & Easy & Dark cream & High & Coarse & Poor & Regular & Regular & Fair \\
\hline Leone Gilobe & Average & Cream & High & Average & Good & Average & Good & Excellent \\
\hline
\end{tabular}


served before cooking, such as color, texture and oxidation tendency, are closely related to the attractive appearance, moisture, and flavor of the cooked tuber. From such observations, a summary evaluation of culinary characteristics was made.

The reanalysis of the 19 varieties revealed more clearly the weaknesses of the majority. Of the original varieties, only 6 were considered to combine

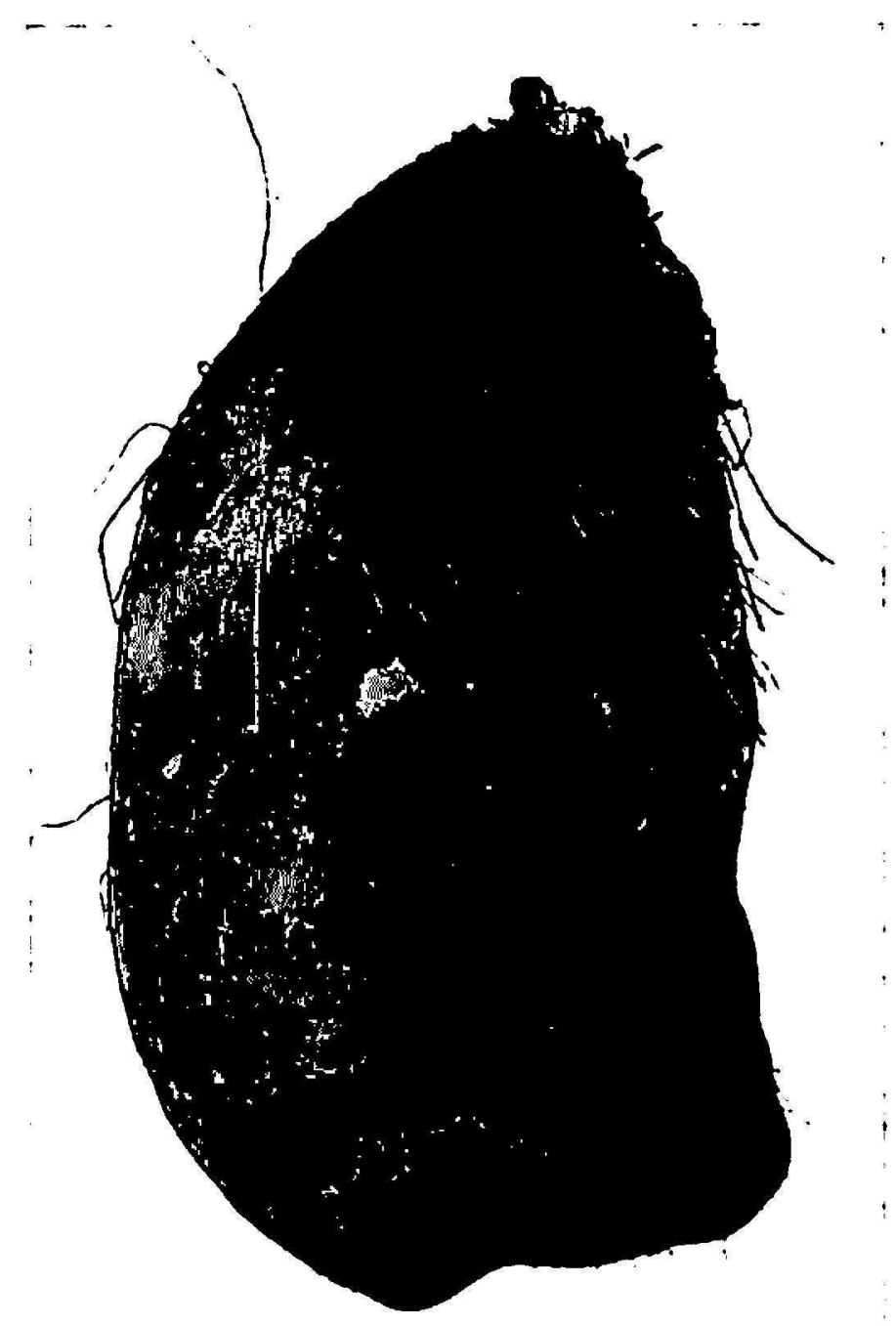

FIG. 1.-Large, solitary tuber of Florido $(\times 0.33)$.

a proportion of desirable characteristies high enough to recommend them as truly fine cultivars for commercial use (table 1).

\section{CHARACTEIRISICS OF THE EIGHT BEST VARIETIES}

\section{FLORIDO}

Early sprouting, leaves arrowshaped and free of anthocyanin, very dark green, very susceptible to leaf spot, virus can be extreme but easily controlled by rogueing, matures early. Tuber (fig. 1) yields high when foliage not damaged by leaf spot. Tubers produred singly or in 2's and 3's, short, 
compact, regular cylinders, surface slightly corrugated by thick bark, almost free of roots. Insect damage to surface frequent. Flesh white to light cream, finely granulated, low flesh oxidation, frequently damaged near surface by nematodes. Excellent cooking quality, good appearance, very good for processing for flour, but too bland for the best fried products. Keeps well in storage. A standard variety in Puerto Rico.

\section{FORASTERO}

Late and irregular sprouting, leaves large and arrowshaped, extremely vigorous growth, free of anthocyanin, susceptible to some but apparently not to all strains of leaf spot and stem rot, apparently resistant to virus, matures late. Excellent yields when not damaged by leaf spot. Tubers (fig. 2)

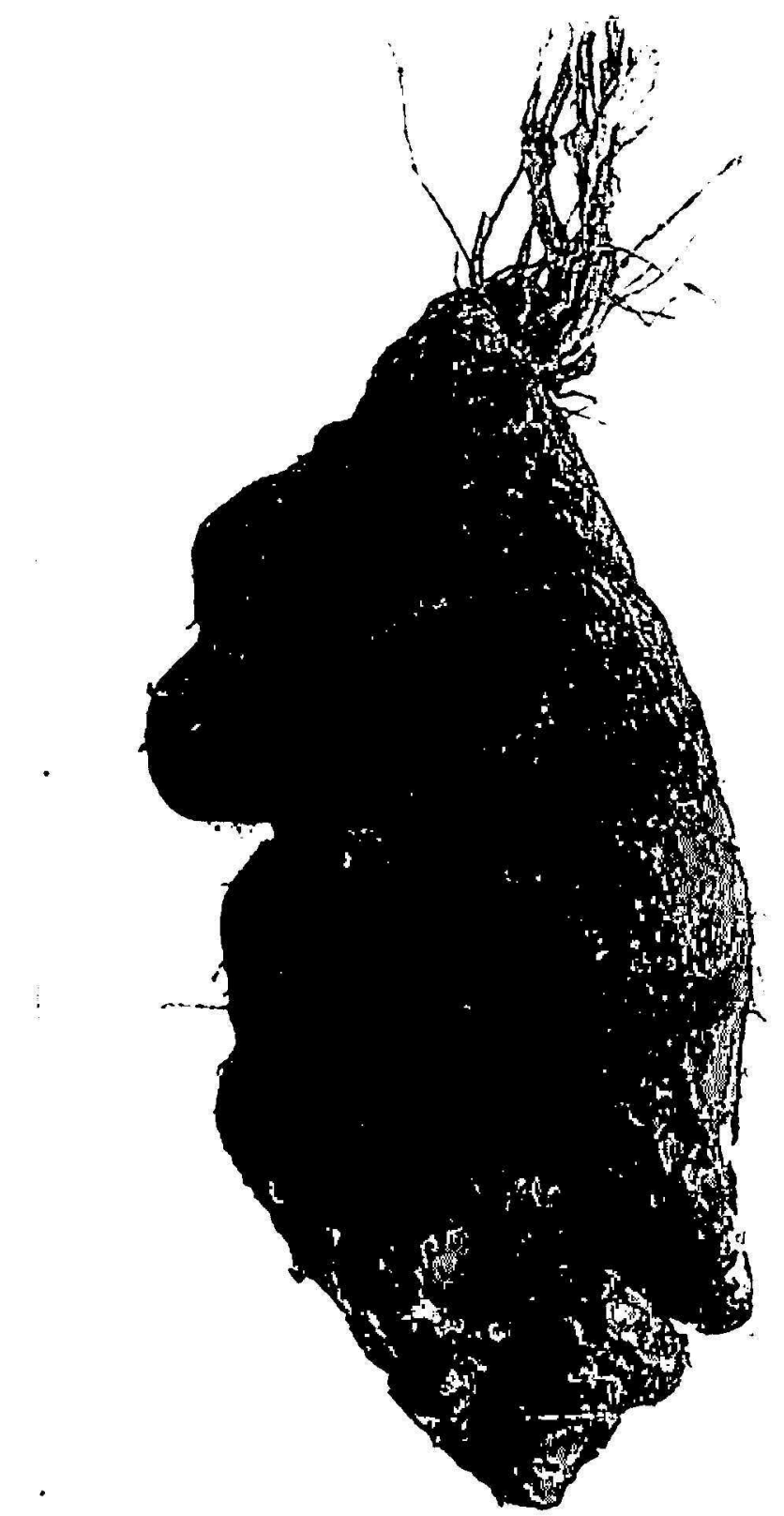

Fia. 2. Somewhat irregular tuber of Forastero $(\times 0.33)$. 
produced singly or in multiples, flattened or bent cylinders, surface smooth and bark thin, almost free of roots. Flesh cream, finely granulated, and compact, low oxidation. The best conking qualities, excellent for fries and for flour, good appearance and taste. Kieeps very well in storage. A variety sometimes seen in western Puerto Rico.

\section{GEMELOS}

Very early sprouting, leaves small and arrowshaped, confused with those of Florido, foliage less extensive than that of lilorido, free of anthocyanin, tolerant or somewhat resistant to leaf spot, viruses not seen thus far in this variety. Matures mid-season, yiclds usually excellent. Tubers (fig. 3) almost always produced in 2's, 3's, or more. Compact cylinders, or with large regular branches, surface rugose due to thick bark, almost free of roots. Flesh white, granular in appearance, low tendency to oxidize. Very good cooking qualities, appearance, and taste after boiling, makes good flour. Fireps well in storage execpt for carly sprouting. A variety

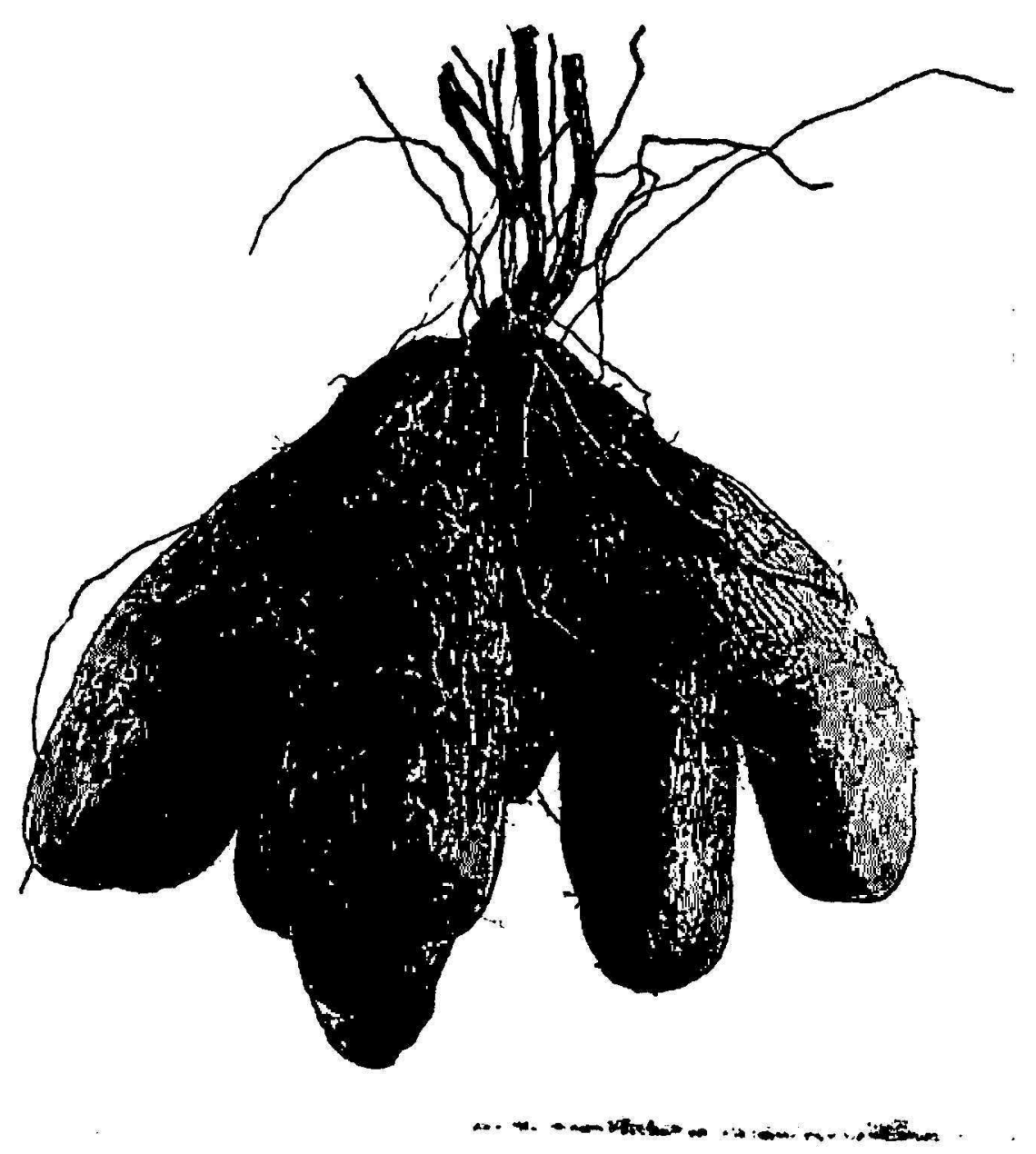

Fıc. 3. Multiple branched tubers of Ciemelos ( $\times 0.33)$. 
selected from unnamed types seen in Puerto Rico. Confused with Florido, but superior in many ways. The smaller plants can be planted somewhat closer than those of other varieties.

\section{LEONE GLOBE}

Late germination, leaves large and arrowshaped, free of anthocyanin, vigorous foliage, light green, resistant to leaf spot and virus, matures late.

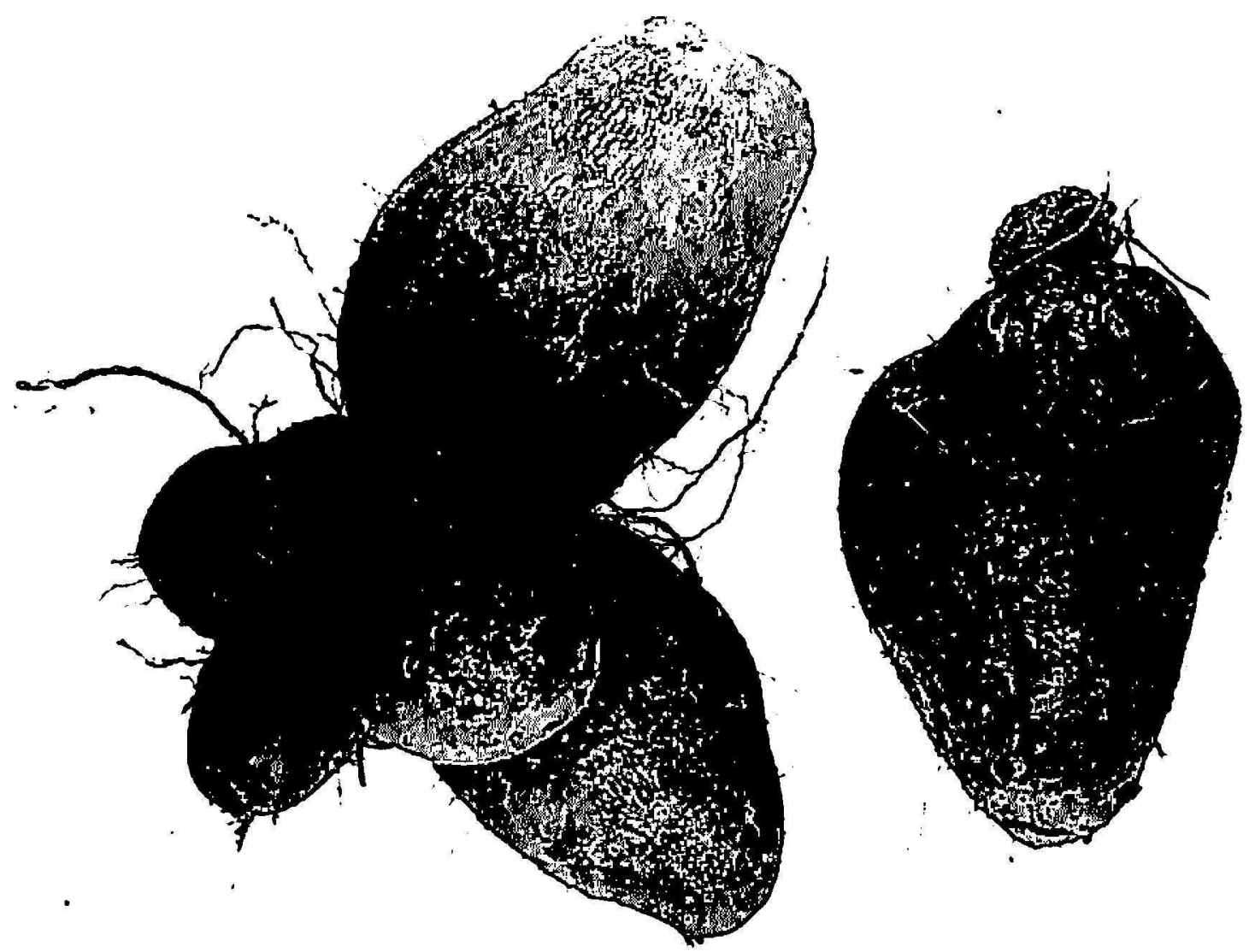

Fig. 4. Single and multiple luhers of leone (ilohe $(\times 0.33)$.

Tubers (fig. 4) produced in groups of 2 to 6 , somewhat spherieal but surface irregular (peeling thus difficult), bark thick, with a few thick surface roots, yiclds very high, insect damage to surface frequent. lilesh white, fine textured, very little oxidation of the flesh. Excellent rooking quality, eolor, flavor, and text ure near perfort. Because of large, spherieal tubers, this is a good variety for processing. lieeps woll in storage if not damaged at harvest. A variety common in Sierra Lcone.

\section{VEEVEN}

Germinates late and sometimes poorly, leaves large, ovate, medium vigor, tolerant of leaf-spot discase, reaction to virus unknown, matures 
mid-season. Tubers (fig. 5) produced singly or in 2's, large, somewhat irregular cylinders, smooth surface free from large roots, bark thick, yields medium to high. Susceptible to insects, which damage the surface. Flesh light cream, granulated texture, flesh oxidation variable. Believed to be quite susceptible to harvest injuries. Good cooking qualities, usually excellent color and good flavor, occasionally polyphenolic oxidation results

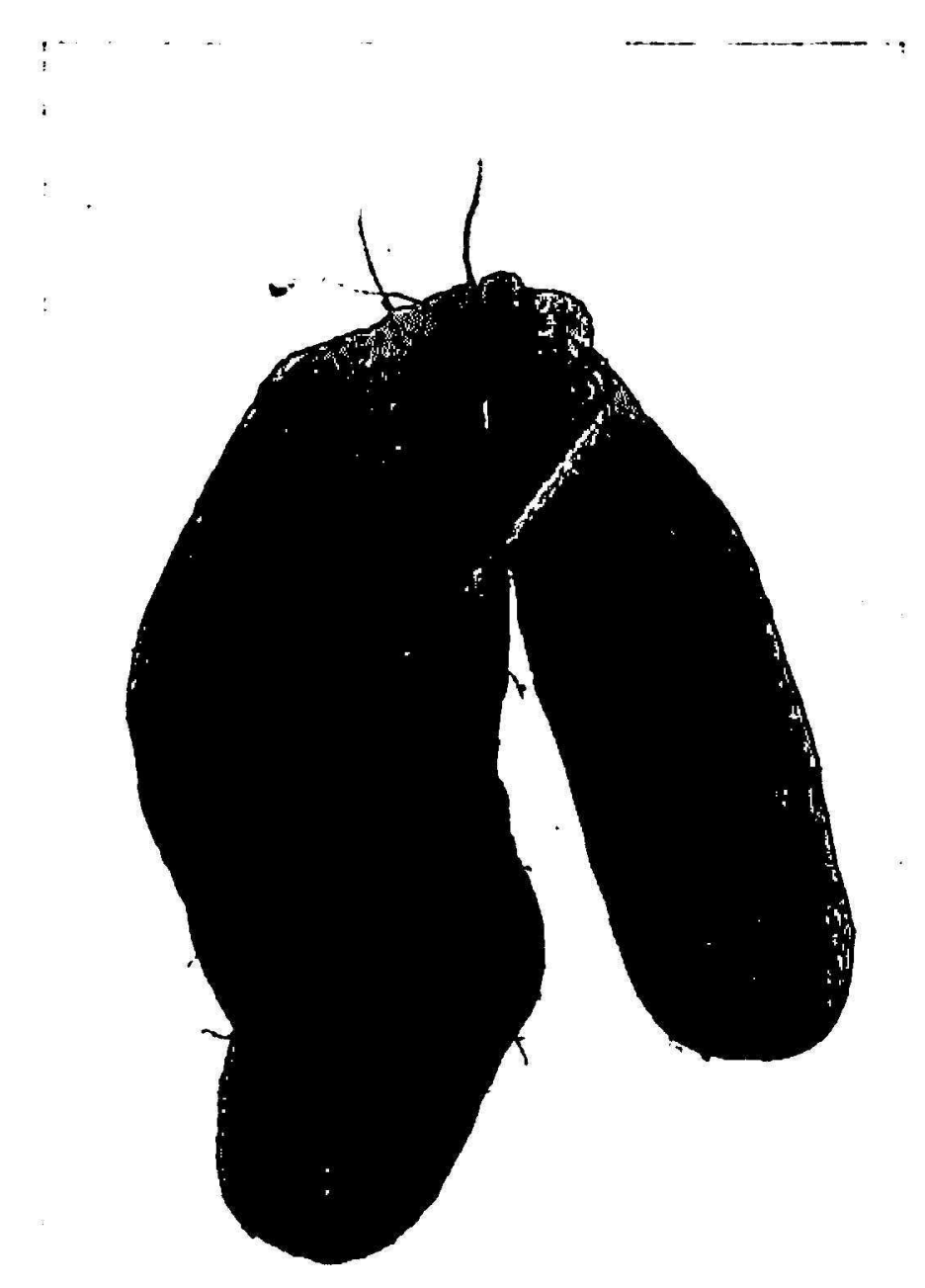

FIti. 5. Jarge, cylindrical tubers of Veeven $(\times 0.33)$.

in gray color and poor flavor. Keeps well in storage. A variety sent from Nigeria.

\section{SMOOTH STATIA}

Late sprouting, leaves medium and ovate in shape, only fair vegetative growth, free of anthocyanin, somewhat tolerant of leaf spot, extremely susceptible to virus, must be kept free of virus by avoidance and rogueing. Matures earlier than most varieties, yields good to very good. Tubers (fig. 6) produced singly or in 2's, large but compact cylinders, very regular in 
shape, surface very smooth and free of roots. Flesh a dark cream color, very grainy in appearance. Medium oxidation, injury and exposure of cut surfaces to the air should be avoided to reduce polyphenolic oxidation. Color and taste usually very good, granular in appearance and taste on cooking. Fair keeping qualities in storage. The tuber is too large for convenient household use. A variety introduced years ago to the Caribbean, but seldom scen because of susceptibility to virus. The virus symptomatology has been reduced by heat treatment of tubers.

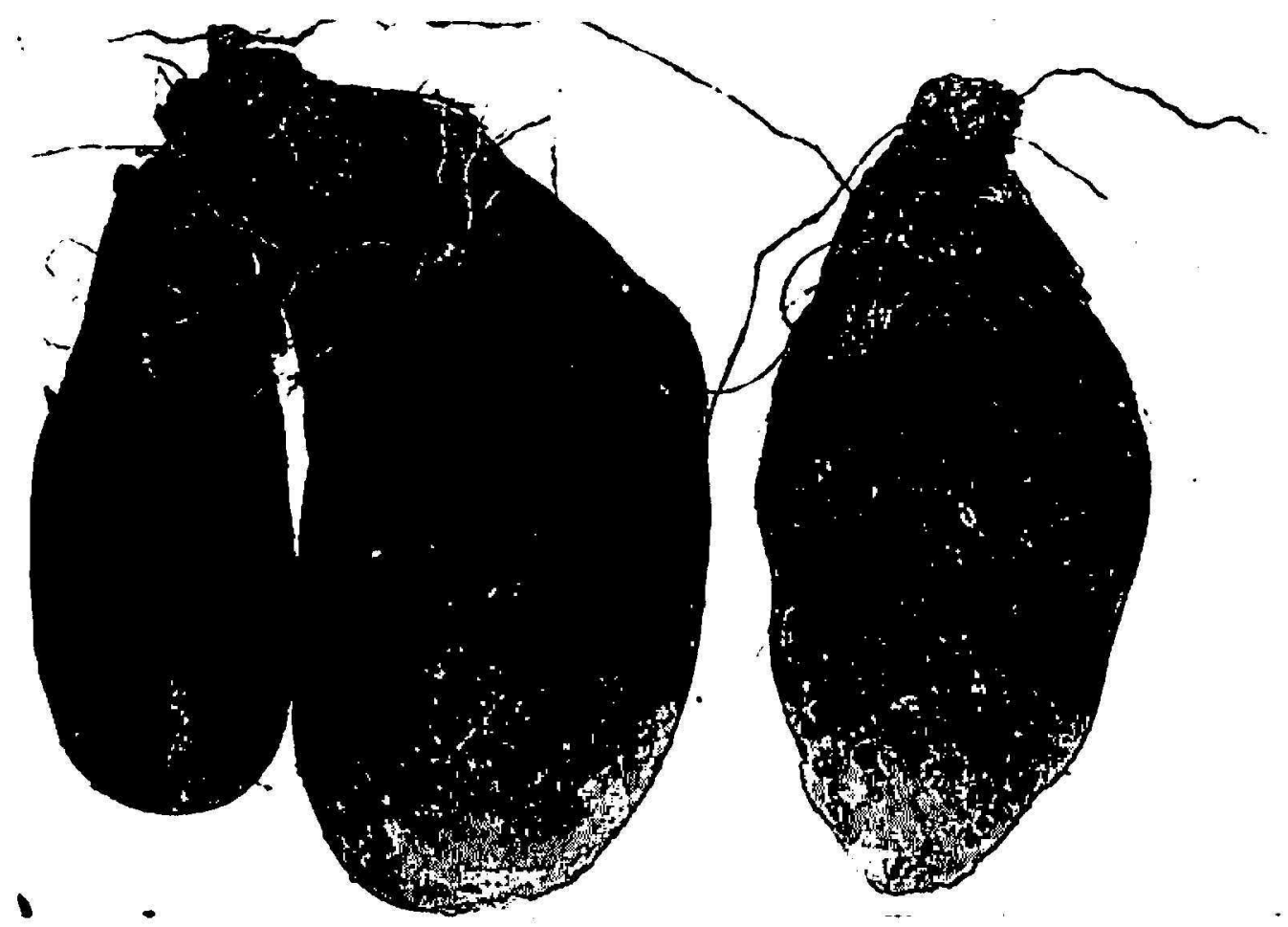

FIg. (i. Compact, cylindrical tubers of Smooth Statia $(\times 0.33)$.

FARM LISBON

Late sprouting, leaves medium in size and ovate in shape, good vegetative growth, free of anthocyanin, tolerant of leaf spot disease, probably carries virus, but with slight symptom expression. Late maturing, yields usually good. There may be a single tuber (fig. 7) or several, each tuber rather pyramidal in shape, the lower half bluntly branched, surface irregular and often covered with fibrous roots, difficult yam to peel. Flesh white to cream, compact and fincly textured, low oxidation tendency. On cooking this is an excellent yam, and very good for fries and flours. The erosion on cooking is more than normal. The flavor and appearance are excellent. Tubers store very well. This variety is a well-known favorite in Trinidad and Barbados, and would merit more attention if it were not for its difficult-to-manage shape. 


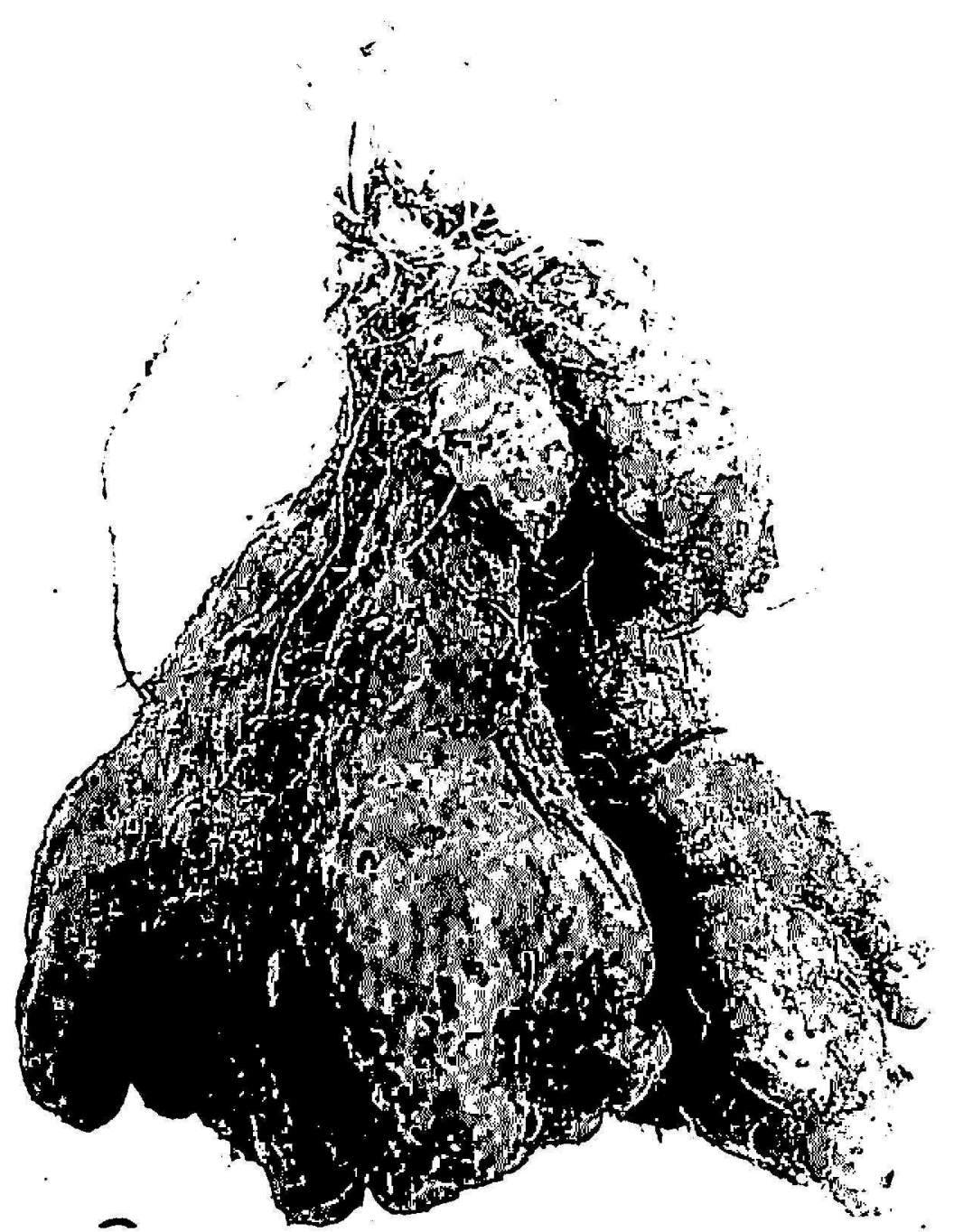

Fig. 7.-The much-branched tuber of Farm Lisbon $(X 0.33)$.

\section{SUIDIE}

Poor and irregular germination, poor to fair foliage production, leaves medium size and ovate shape, moderately susceptible to leaf-spot discase and probably carrying a virus. Matures mid-scason, and yields fair to average. Tubers (fig. 8) usually produced singly, spindle-shaped to long, uniform cylinders, surface smooth with few surface roots. Flesh white, low oxidation, finely textured but not dense. Rather soft and easily eroded by cooking, excellent appearance and flavor, very good for chips and fries. Very poor storage qualities, tubers rot easily where injured. A varicty collected in the Ivory Coast that would have little value were it not for its very excellent cooking qualities. 


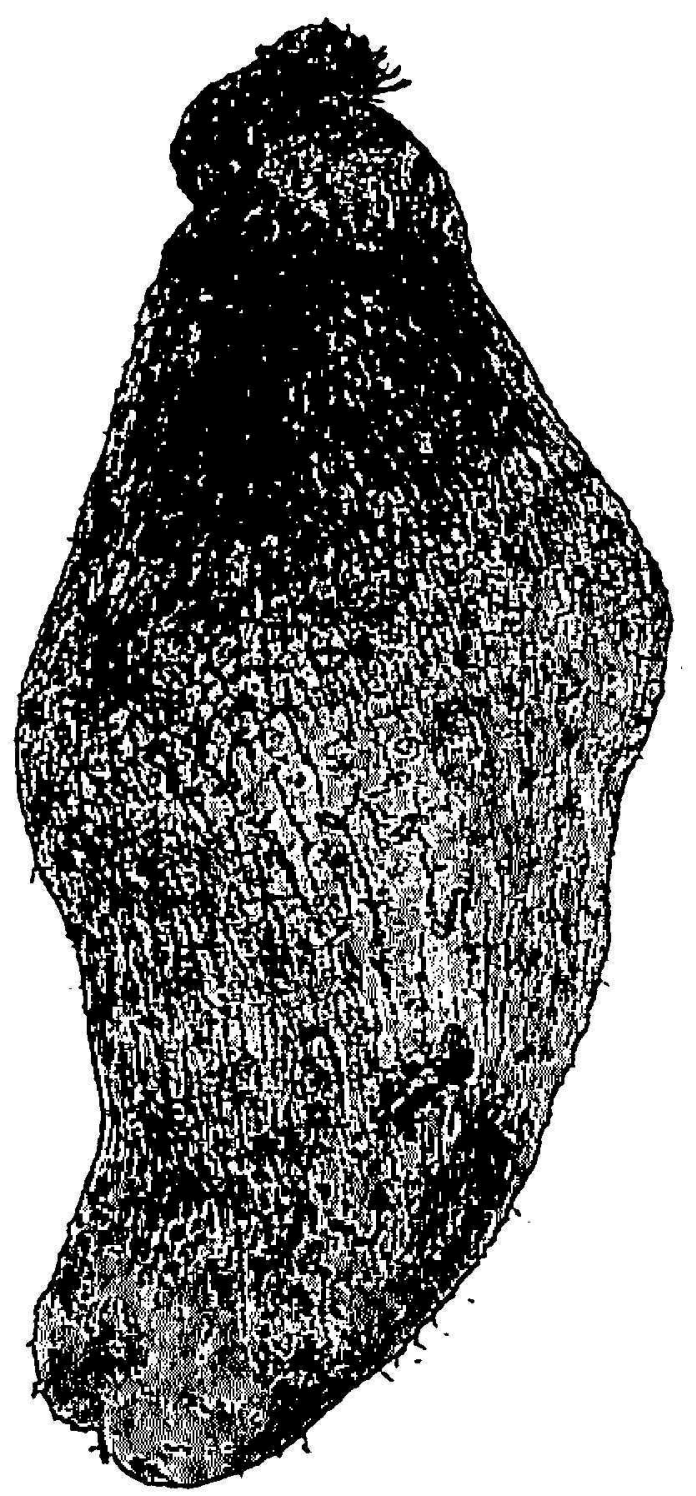

Fici. 8. A shorter than normal tuber of suidie $(\times 0.33)$.

\section{YIELDS}

Typieal yiolds of the bottor varioties are given in table 5. Yields varied acerording 10 troitments, yours, and locations, as expected. No offort is made here to treat these differencess statistieally. lexeept when plants are discetsed, average yields of the seleceled varieties reach 20 tons or more per hectare. Whon maximum conditions for growth are maintained (organic material added to the soil and vines supported adecquately), yields of 30 tons per heretare or more can be realized. These yiolds must be cont rasted with those of larger, roarse tuber varieties that yield 50 or 60 tons per 
hectare in Puerto Rico and suitable only for consumption by animals or for processing under favorable conditions.

\section{DISCUSSION}

Introduction of yam cultivars from worldwide sources has made it possible to obtain considerable insight into the variation and potential of Dioscorea alata. Findings suggest very poor distribution of the better

Table 5.-Yields (lons per hectare) of selected Dioscorea alnta varictiss in Puerlo Rico

\begin{tabular}{lcccccc}
\hline \multirow{2}{*}{ Variety } & & \multicolumn{2}{c}{ Site and circumstances of the planting } & \\
\cline { 5 - 6 } & & A & B & C & D & E \\
\hline Florido & 29.4 & 20.9 & 17.7 & - & 18.4 \\
Forastero & 23.8 & $14.0^{2}$ & 27.4 & $14.4^{2}$ & 43.2 \\
Gemelos & - & - & 19.7 & $25.0,20.2^{3}$ & 21.6 \\
Leone Globe & - & - & - & 25.0 & 42.4 \\
Smooth Statia & $13.1^{4}$ & - & - & 10.3 & - \\
Veeven & - & - & 19.9 & 18.0 & 20.0 \\
Farm Lisbon & $29.4,38.2^{3}$ & 24.7 & 26.9 & $21.4,32.3^{3}$ & - \\
Suidie & - & - & 15.2 & 16.4 & - \\
\hline
\end{tabular}

1 Site and circumstances of planting:

A Mayagïez, planted in ridges, spaced $0.6 \times 1.6$ meters, organic material added to soil, individual plants staked.

$B$ Isabela, planted in ridges, spaced $0.6 \times 1.6$ meters, mineral fertilizer, wire and string support.

C Isabela, planted in ridges, spaced $0.4 \times 1.6$ meters, mineral fertilizer, no staking system.

D Isabela, planted in ridges, spaced $0.6 \times 1.6$ meters, mineral fertilizer, no staking system.

E Caguas, planted in hills, spaced $0.45 \times 0.68$ meters, mineral fertilizer, no staking system.

2 Diseased, leaf spot.

${ }^{3}$ Yield of two different plots grown at the same time.

4 Diseased, virus.

varieties and the consequent use of inferior types in many regions that would not be used if better varieties were known. In many yam-growing regions, rapid progress in quality improvement can be made by introduction and propagation of superior types.

A potential obstacle to introduction of yams from one geogruphical area to another is the presence in some varieties of virus-like symptoms. When symptoms are severe, yields of individual plants are reduced. The disease has not received much attention in this species and its potential for spread or threat to the industry is an unknown factor. However, in small plantings, rigorous rogueing of infected plants, followed by regular 
selection of large tubers for seed purposes hold the disease in check or reduce symptoms to almost zero. Virus-like symptoms have been found in yams from every geographical area sampled, and this suggests that the disease or diseases already are widespread. Extreme caution is thus necessary, as in the carrying out of any plant or animal introduction program.

\section{RESUMEN}

Una colección de 300 variedades de ñame de agua (Dioscorea alala) de diversas regiones del trópico fue evaluada tomando en consideración 100 características observables de campo, de laboratorio y culinarias. De estas observaciones se desarrollaron conceptos de calidad usados para seleccionar variedades superiores. Se seleccionaron seis variedades excelentes de tipo comercial (Florido, Smooth Statia, Forastero, Veeven, Gemelos y Leone (ilobe), las cuales están ahora disponibles para distribuirse a países tropicales. 